\title{
How Not to Make a Mexican Musical: Luis Buñuel and the Perils of Mexicanidad.
}

Luis Buñuel is a truly transnational and transcultural figure whose cinematic work took him from his native Spain to France, Hollywood and Mexico. After completing his studies in Madrid in 1925, he went to Paris, where he made his first film, in collaboration with Salvador Dalí, the surrealist Un chien andalou (1929). ${ }^{1}$

When he returned to Paris a decade later, having fled the Spanish Civil War, he produced propaganda films for the Republic. He then moved to the United States, where, during World War II, he was employed by the Museum of Modern Art in New York to edit and dub 'nontheatrical films, on topics ranging from defense production to science and health, for distribution in Latin America

In 1961, he returned to Spain from Mexico to make Viridiana, which won the Palme d'Or at Cannes but was banned in Spain. The uproar surrounding the banning of the film led Franco himself to watch it, and though according to Buñuel, he did not consider it offensive, neither did he overturn the decision to censor it. ${ }^{2}$ The year 1966 marked the beginning of the very successful late period of his career, when he made six films in France, including Le Charme discret de la bourgeoisie, which was awarded the Academy Award for Best Foreign Film in 1972. ${ }^{3}$

Since his work spans almost half a century and an extraordinary geographical and thematic range, this chapter will focus on his work in Mexico, and particularly on his initial experiences as a director there. Contemporary critics unite in paying tribute to Buñuel's contribution to the Mexican film industry. In a survey of 300 members of the public conducted between December 1990 and February 1991, on the occasion of the exhibition 'Revision of Mexican Cinema' at the Palacio de Bellas Artes, Mexico City, Buñuel ranked third in a list of favourite directors. ${ }^{4}$ More recently, Jason Wood has observed that Buñuel is 'inextricably linked to the development of Mexican cinema and remains one of its most prominent and influential figures', adding that his unsentimental examination of social problems and his ability to work creatively with

\footnotetext{
${ }^{1}$ Buñuel, Luis, Mi último suspiro, (Barcelona: Random House Mondadori, 2004), pp. 89-119.

${ }^{2}$ Buñuel, 2004, p. 279.

${ }^{3}$ Krohn, Bill, and Duncan Paul, eds., Luis Buñuel: The Complete Films, ((Köln: Taschen, 2005,) p. 167.

${ }^{4}$ García Canclini, Néstor, Los nuevos espectadores: Cine, televisón y video en México, (Mexico: Instituto Mexicano de Cinematografía, 1993), p.68.
} 
small budgets link him to $21^{\text {st }}$-century directors. ${ }^{5}$ Given such glowing tributes, it is surprising to note that the director's initial foray into Mexican filmmaking was less than successful and that this rocky start was compounded by the hostile reception of his third Mexican feature, Los olvidados (1950). The initially unfavourable reaction to his work says much about the importance of mexicanidad, or the portrayal of a distinct Mexican identity, in the films made during the so-called Golden Age of Mexican cinema. This chapter examines the ways in which the director's refusal to adhere to the tenets of cinematic mexicanidad was to cost him dear in his early career in Mexico and how his failure to observe the generic staples of the Mexican musical in particular led to the poor performance of his first Mexican feature Gran Casino.

\section{Mexicanidad and Golden Age Cinema}

Mexicanidad has been defined as 'a movement that gave Mexico a sense of its own identity and produced a creative explosion in literature, painting, and film. ${ }^{9}$ One of the most notable initial expressions of this distinct identity was through mural art, which grew out of a:

Mexican cultural renaissance, the roots of which were clearly present and developing before the revolution. The renaissance synthesized with the political revolution to form a unique relationship between a tide of radical national politics and a cultural rediscovery of national definition and identity that would in the end reach beyond the purely Mexican [...] The growth of popular art [... ]led to an explosion of work representing each and any subject that was Mexican. ${ }^{7}$

\footnotetext{
${ }^{5}$ Wood, Jason, The Faber Book of Mexican Cinema,' (London: Faber \& Faber, 2006), p.3.

${ }^{6}$ William Foster, David, ed., Mexican Literature: A History, (Austin: University of Texas Press, 1996), p. 243

${ }^{7}$ Rochfort, Desmond, Mexican Muralists, (San Francisco: Chronicle Books, 1993), p.15.
} 
While the roots of mexicanidad were inextricably linked to a burgeoning nationalist consciousness that rejected the Eurocentric ideas of dictator Porfirio Díaz, it was not a provincial movement. The great muralists to emerge in early $20^{\text {th }}$-century Mexico, among them Diego Rivera, certainly concentrated on Mexican themes and images in their work but they also travelled widely and incorporated global influences into their work. This synthesis of the national and the international is also evident in the films that were made during arguably the most successful period of filmmaking in Mexico, the Golden Age. As Dolores Tierney points out, its name derives from the dual character of the films produced within its rubric:

The name 'Golden' clearly refers to this cinema's gilded, idealized representations of Mexican life. Yet the Golden Age was also a period when, despite the use of Hollywood structures of production and its stylistic and narrative technique, Mexican filmmakers were able to forge what is perceived as a distinctly national cinema. ${ }^{9}$

Perhaps the most enduringly popular and influential film of Mexico's golden age, Fernando de Fuentes's 1936 Allá en el Rancho Grande, combines a strong nationalistic flavour with an adaptation of Hollywood formulas, such as the singing cowboy films popularised by Gene Autry and Roy Rogers, to Mexican tastes. ${ }^{10}$ As Ramírez Berg observes, de Fuentes's film established the Mexican genre known as the comedia ranchera and prescribed many of its conventions: “ . . generously interspersed musical numbers punctuating a romantic story — typically a boy-meets-

\footnotetext{
${ }^{9}$ Dolores Tierney 'Silver sling-backs and Mexican Melodrama: Salón México and Danzón,' Screen, (Vol.38, No. 4, winter 1997), pp. 360-371, p. 360.

${ }^{10}$ See Carlos Monsiváis in King, John, Mediating Two Worlds, (London: British Film Institute, 1993), p.141 and Ramírez Berg, Charles, Cinema of Solitude: A Critical Study of Mexican Film, 1967-1983, (Austin: University of Texas Press,) 1992, p. 98.
} 
girl, gets-girl story or a tale of rivals (best friends, brothers, cousins) vying for the favor of a beautiful girl."11 Allá en el Rancho Grande revolves around a romantic conflict between Felipe, who has inherited the Rancho Grande from his father, and José Francisco, played by Tito Guizar, Felipe's best friend from childhood and the foreman of his ranch. Both men are in love with the beautiful Cruz, played by Esther Fernández, who is engaged to José Francisco. Cruz's godmother arranges to prostitute the unwitting Cruz to Felipe for a night, but the asthmatic girl faints and her virtue remains intact, while Felipe discovers that Cruz and José Francisco are in love and apologizes to her. José Francisco learns of the meeting and plans to kill Felipe, but the latter convinces him that nothing happened between himself and Cruz. Harmony is restored when Cruz and José Francisco marry at the film's conclusion.

Allá en el Rancho Grande is characterised above all by its glorification of rural life. Its nostalgic tone is suggested by the song that gives the film its name, which is sung from the point of view of a person looking back on the idyllic life he enjoyed on the ranch. The film's sentimental quality is further underscored by the many musical interludes, which both appeal to female viewers in their presentation of tender yet masculine male characters and form a sense of group cohesiveness in their use of well-known traditional songs familiar to the audience. Perhaps the most striking aspect of the mise en scène is the extremely close-knit community at the heart of the Rancho Grande. To view the film as a microcosm of an ideal Mexico takes no great leap of the imagination. At the time it was made, most Mexicans lived in rural communities and mass migration to Mexico City had not become a widespread phenomenon. While it has been criticized for portraying the ranch owners as

\footnotetext{
${ }^{11}$ Ramírez Berg, Charles, 1992, p. 98.
} 
benevolent dictators, thus echoing the nostalgic view of the deposed Porfirio Díaz still held by many Mexicans in the wake of the Revolution, the film's success was more the result of its articulation of mexicanidad through music.

as García Riera notes:

habría que esperar el enorme éxito de Allá en el Rancho Grande (1936) para que se entendiera lo que después pudo parecer obvio: sería la explotación del folclor mexicano, del color local y, sobre todo, de las canciones, lo que daría al cine mexicano su solvencia comercial en todo el continente americano.

(The enormous success of Allá en el Rancho Grande (1936) was to be expected, and it allows us to understand what might seem obvious in its wake: that the exploitation of Mexican folklore, local colour, and especially, songs, would give Mexican cinema its commercial success throughout the American continent. $)^{12}$

As the above comment suggests, Allá en el Rancho Grande transformed the Mexican film industry and delighted audiences both in Mexico and throughout Latin America, as well as in the Spanish-speaking regions of the United States. ${ }^{13}$ Its success revitalised film production in Mexico, moreover. In 1936, 24 Mexican films were made, a number that increased to 38 a year later and to 58 in $1938 .^{14}$ The comedia ranchera genre was virtually exhausted as early as 1939 because of market saturation with films that presented an idealised depiction of ranch life. Nonetheless, De

\footnotetext{
${ }^{12}$ Emilio García Riera, Breve historia del cine mexicano: Primer siglo 1897-1997, (Mexico City: Ediciones Mapa, 1998,) p. 81.

${ }^{13}$ Emilio García Riera, 'The Impact of Rancho Grande,' in Paranaguá, Paulo Antonio, ed., Mexican Cinema, (London: BFI, 1995,) p. 128.

${ }^{14}$ Emilio García Riera, 1998, p. 102.
} 
Fuentes's film remained a watershed that pointed to new possibilities in the presentation of the nation and its culture.

Despite the obvious limitations of genre films such as the comedia ranchera, they led to a renewed confidence in native talent, to the extent that in 1939, President Cárdenas decreed that every cinema should screen at least one Mexican film each month. ${ }^{15}$ Critics disagree about the length of time that can be considered Mexican cinema's Golden Age, but most agree that it spanned the 20-year era from 1935 to $1955 .^{16}$ The films produced over these two decades both reflected life in Mexico, albeit with an emphasis on the positive aspects of society, and profoundly shaped it. One of the most enduring genres to emerge at this time was the melodrama, which normally centred on the family. The Revolution remained a popular theme, and many films were set in distinctly Mexican locales such as the cabaret, the dance hall, the cantina and the boxing ring. The very banality of these stories and their settings proved to be the key to their popularity, as Monsiváis argues:

The so-called Golden Age, between 1935 and 1955 more or less, was in reality the period of an alliance between the film industry and the audiences of the faithful, between the films and the communities that saw themselves represented there. During those years, in many parts of Latin America, those communities watched those films and saw themselves in them, distinct and recognisable. What today is described as an exasperating naivety in the majority of these films had more to do with the technical ineptitude of directors and 'stars' in particular, and with the lack of any critical response on the part of the audience. For a long

\footnotetext{
${ }^{15}$ Carlos Monsiváis, Historia general de México, 1998, p. 1520.

${ }^{16}$ Carlos Monsiváis, 'Mexican Cinema: Of Myths and Demystifications,' in King, 1993, p. 142.
} 
period they considered films to be neither art nor spectacle but rather the continuation of everyday life, the believable explanation of the meaning of their lives. ${ }^{17}$

The overwhelming success of the films produced during the Golden Age certainly suggests that audiences were not keen to be challenged by polemical examinations of society and were happy to passively enjoy spectacles that confirmed the mexicanidad of their own lives.

Monsiváis dismisses the aesthetic qualities of the films too lightly, however. The film boom during this period owed a great debt to the high production values of national cinema, as well as the availability of a diverse range of stars with whom audiences could identify. Economic factors also played a significant role. In 1942, the Banco Cinematográfico was established to provide loans that would foster the cinema industry. ${ }^{18}$ An added boost came from Mexico's chief cinematic rival, the United States. As World War II raged, the United States sought the support of as many allies as possible. Mexico's cooperation was fostered through Nelson Rockefeller's Office of the Coordinator of Inter-American Affairs. Mexico, which supported the Allies, was granted loans, technical aid and precious film stock, the production of which was restricted because cellulose was needed for the manufacture of explosives. ${ }^{19}$ The end of the war also brought an end to the support of Mexico's film industry by its northern neighbour, however, Hollywood dominated local markets once more, and the amount of film stock allocated to Mexico sharply

\footnotetext{
${ }^{17}$ Carlos Monsiváis, in King, 1993, p. 142.

${ }^{18}$ Jaime Tello, 'Notas sobre la política económica del "viejo" cine mexicano,' Hojas de cine, 1988, p. 23.

${ }^{19}$ Édgar Soberón Torchia, Un siglo de cine, (Mexico City: Cinememoria, 1995), p. 218.
} 
declined. ${ }^{20}$ What is more, the increasing sophistication of audiences, who had by now seen almost 20 years of North American, European and national productions, made the established genres seem lacking in novelty. The rapid urbanisation of Mexico meant that films glorifying rural life no longer reflected the experiences of a large proportion of the population. The films of the late 1940s and early 1950s reflected this crossroads in the tension between filmmakers who sought to prolong the Golden Age style and a new generation who began to make unromantic, gritty urban dramas.

\section{Buñuel's Early Career in Mexico}

Buñuel's first Mexican feature clearly sought to emulate the success of Golden Age musicals. He was employed by producer Oscar Dancigers to direct Gran Casino in Mexico in 1946, after he had moved from New York. The films made by Buñuel in Mexico seldom attract critical acclaim. As Robert J. Miles notes, the director had voiced a reluctance to visit Latin America before he went to live in Mexico, and this may well be reflected in the uneven quality of his work there. ${ }^{21}$ Buñuel's Mexican directoral debut in particular has been afforded little critical attention. It only merits a passing reference, for example, in Iván Humberto and Ávila Dueñas' study of the director's Mexican films and is not analyzed in detail like his other Mexican films. ${ }^{22}$ Moreover, Caryn Connelly and Juliet Lynd, who argue persuasively that the sheer volume of films made by the director in Mexico means that they 'demand a reconsideration,' do not so much as mention Gran Casino in their study of his work. ${ }^{23}$ Although the combination of the acclaimed Spanish director and the leading Mexican musical star Jorge Negrete in the lead role must have seemed like the recipe for a surefire hit, there is general agreement that Gran Casino is far from his greatest work. At the time of its making, the director has been away from film directing for a number

\footnotetext{
${ }^{20}$ Ramírez Berg, 1992, p. 39.

${ }^{21}$ Miles , Robert J., 'Virgin on the Edge: Luis Buñuel's Transnational Trope,' Studies in Hispanic Cinemas, Volume 2 Number 3, pp. 169-188, p. 169.

${ }^{22}$ Humberto, Iván, and Dueñas, Ávila, El cine mexicano de Buñuel: Estudio analítico de los argumentos y personajes, Mexico: Insitituto Mexicano de Ciinematografía, 1994), p.285.

${ }^{23}$ Connelly, Caryn, and Lynd, Juliet, 'Virgins, Brides and Devils in Disguise: Buñuel does Mexican Melodrama,' Quarterly Review of Film \& Video, Vol 18(3), pp. 235-56, pp. 235.
} 
of years. ${ }^{24}$ Moreover, it was made at a time when the genres that had led to the unprecedented success of Mexican cinema in the early years of the Golden Age, particularly the musical, were becoming less popular. As Ernesto Acevedo-Muñoz, observes:

Not only was Buñuel new to Mexican cinema (if certainly not to the musical melodrama), but Mexican cinema was changing. Despite the stability of "family" melodramas and comedias rancheras, the conservative classical musical was evolving into the more risqué cabaretera film that was so culturally specific to the sexenio of President Alemán between 1946 and 1952. ${ }^{25}$

Although Gran Casino is set in a cabaret, its style owes much more to the classic musical than the more daring cabaratera genre. The musical numbers that permeate the film are not confined to the stage, so that it more closely resembles the comedia ranchera in its use of music to punctuate the film. Even the numbers that are sung on stage do not conform to the tendency to use rumba and mambo to denote a daring, permissive atmosphere. Buñuel could not bring himself to adhere rigidly to stock musical formulas, moreover. As Víctor Fuentes suggests, even in his Mexican films that are regarded by critics as inferior or frankly bad, the director insisted that he always found a way to put his own mark on them:

Yo procuraba que en cada película hubiera siempre un escape, que siempre tuviera un senderillo por donde me iba a hacer lo que quería...

(I tried to ensure that in every film there was always an escape route, that I would always have some little path that would allow me to do what I wanted.) ${ }^{26}$

In Gran Casino, a commissioned film that would to a large extent determine whether Buñuel would have a career in Mexico, such pathways were severely restricted. Much more problematically for a Mexican audience, Buñuel was faced with the prospect of dealing with two world-famous musical stars from different countries, Negrete from

\footnotetext{
${ }^{24}$ Edwards, Gwynne ,A Companion to Luis Buñuel, (Suffolk:Tamesis, 2005), p. 7.

${ }^{25}$ Acevedo-Muñoz, Ernesto R., Buñuel and Mexico: The Crisis of National Cinema, (Berkeley: University of California Press, 2003), p.46

${ }^{26}$ Fuentes, Víctor ,Buñuel en México, (Spain: Instituto de Estudios Turolenses, 1993), p. 39.
} 
Mexico and Libertad Lamarque from Argentina. ${ }^{27}$ It was Lamarque's first appearance in a Mexican feature, after she was forced to leave Argentina for criticizing Eva Duarte's inferior acting on the set of the film Circus Cavalcade. ${ }^{28}$ Lamarque was as famous in her country as Negrete was in his, thus she required equal billing and an equally prominent role, which lent a distinctly Argentine musical flavour to the film that must have been baffling to audiences accustomed to the reinforcement of mexicanidad through the songs that punctuated typical musicals. The romance between Negrete's charro and the glamorous but prim Argentinean would have been far more plausible in real life than it plays on the screen, furthermore. It is so unconvincing that it was bound to be rejected even by audiences well used to suspending disbelief.

Like Allá en el Rancho Grande, the film opens to the accompaniment of Mexican folk music as we are introduced to Negrete's character, Gerardo, and his friend Heriberto in their prison cell. Having been denied release, despite the fact that they have spent three days there and were only sentenced to one, they decide to escape by sawing through the bars of their cell. To distract from the noise, Gerardo bursts into the film's first musical number, the love song 'Dueña de mi amor, (Mistress of My Love)' accompanied by his own guitar playing and the incongruous presence of the Trío Calaveras, who bizarrely appear in the cell opposite to provide a chorus. This ruse allows Gerardo and Heriberto to flee to Tampico, where they have heard that they can make a fortune working in oil fields. The camera cuts to an oil field called La Nacional, and its Argentine owner, Don José Enrique Irigoyen, being threatened by local henchman Fabio, who operates on behalf of a shady company called Van Eckerman. This company wants to control all the oil production in the area, and thus Fabio attempts to intimidate Irigoyen into selling, while also scaring prospective workers so that they will not work his fields. Gerardo and Heriberto are not intimidated, however, and agree to work for the Argentine. With the help of the escaped prisoners, La Nacional becomes a thriving business. As the owner and his workers celebrate this triumph, Irigoyen announces the imminent arrival of his sister, whom he has not seen for many years. Gerardo and Irigoyen continue their

\footnotetext{
${ }^{27}$ Krohn, Bill, and Duncan, Paul, eds., Luis Buñuel: The Complete Films, (Köln: Taschen, 2005,) p. 58.

${ }^{28}$ Levine, Suzanne Jill, Manuel Puig and the Spider Woman: His Life and Fictions, (Wisconsin: University of Wisconsin Press, 2001), p. 69.
} 
celebration at the Gran Casino, but after going upstairs with the seductive salon girl Camelia, Irigoyen disappears. It is left to Gerardo to explain the situation to his sister Mercedes, who initially suspects that he has murdered her brother in order to take over his business. In order to investigate the situation, she pretends to be her own servant, Raquel, rather than Irigoyen's sister, and takes a job as a singer in the Gran Casino. There she discovers the truth about the murky dealings of the Van Eckerman company, which also runs the casino. She reveals her true identity to Gerardo, who accepts her as his new boss and tells her that her brother left orders to blow up the wells rather than let the Van Eckerman company take them over. A final confrontation occurs between Fabio and Gerardo at the casino, with the latter being taken prisoner. Mercedes goes to Van Eckerman and agrees to sell him La Nacional in exchange for Gerardo's life. As Mercedes and Gerardo flee the town by train, explosions sound as the wells are blown up.

As Agustín Sánchez Vidal notes, it has become customary for critics to look for typical Buñuel touches that redeem his less well-received films. He identifies these touches in Gran Casino as follows:

Uno de ellos es la resolución de una escena amorosa intercalando entre el beso de Negrete y Lamarque la aparición de una rama que remueve el lodo. Otro podría ser la inverosímil presencia de un gaitero escocés con cuerpo de baile incluido en el escenario del casino o los insospechados lugares en los que se coloca al Trío Calaveras, acompañando a Negrete en cuanto éste rompe a cantar. (One of these is the resolution of a love scene that inserts in the middle of the kiss between Negrete and Lamarque a shot of a branch stirring mud. Another could be the incongruous presence of a Scottish piper and a dance troupe on the stage of the casino, or the unexpected places where the Trío Calaveras appear, accompanying Negrete every time he bursts into song. $)^{29}$

The second example listed here is indicative of Buñuel's irreverent approach to the musical genre, which may well have been the primary reason for his film's lack of success. Although it was commonplace for trios to accompany a musical's stars,

${ }^{29}$ Sánchez Vidal, Agustín Luis Buñuel, (Madrid: Cátedra, 1994,) p. 148. 
nowhere has the sudden appearance of the Trio seemed as unlikely and even startling as in Gran Casino. Indeed, Buñuel's constant placing of the Trio in improbable and often impossible locations or situations amounts to a parody of the presence of these groups in such films. Similarly, the presence of diverse musical styles, from Scottish pipes to opera on the stage of the Gran Casino was a dramatic and jarring departure from the use of music to signify mexicanidad. This is particularly true of the scene in which Irigoyen and Gerardo bond over music, which sees Gerardo sing a paean to Argentina, 'Adiós pampa mía, (Goodbye, My Pampa)' in a radical departure from his characteristic hymns to Mexico. Lamarque's musical numbers are also too coloured by her nationality to have been overly appealing to Mexican audiences, as she specialized in tango numbers that were intimately associated with Argentina and not mexicanidad. Writing of the success of the films of Emilio Fernández, David Ramon notes that there was one crucial factor that any successful director grasped:

Él se da cuenta de que las cosas fundamentales que habían interesado al público tanto del cine más verdadero come en el muy falso...eran el héroe y las canciones.

(He realizes that the fundamental elements that have captured the public in both the most true to life and false films were the hero and the songs. $)^{30}$

This view that the songs were as important as the hero in ensuring the success of a musical is reiterated by Carlos Bonfil, writing on Nosotros los pobres, an enduringly successful film made in the same year as Gran Casino and starring Jorge Negrete's counterpart Pedro Infante:

En el Cine Colonial una congregación de feligreses hace de Nosotros los pobres una película de culta avant la lettre, y si no memoriza los diálogos de Pedro de Urdimales, sí conoce en cambio a la perfección las canciones de Manuel Esperón, y se identifica con la galería de personajes que es catálogo entrañable de prototipos...

\footnotetext{
${ }^{30}$ Ramon, David ,'Lectura de las imagines propuestas por el cine mexicano de los años treinta a la fecha,' de los Reyes, Aurelio, and Amador, María Luisa, eds., Exposición 80 años de cine en México, (Mexico: Imprenta Madera S.A., 1977), p. 96.
} 
(In the Colonial Cinema, a congregation of parishioners makes Nosotros los pobres a cult film avant la lettre, and if it doesn't memorise the dialogues written by Pedro de Urdimales, it certainly knows by heart the songs written by Manuel Esperón, and it identifies with the gallery of characters that is a lovable catalogue of prototypes. $)^{31}$

Indeed, a comparison between the function of music in Nosotros los pobres and Gran Casino illustrates just how much Buñuel deviated from the typical use of music in Mexican films. Nosotros los pobres opens with a lengthy written introduction warning audiences that they will see some disturbing scenes but assuring them that poverty, far from being a sin, is a virtue. The camera then pans to an urban barrio, where the characters join in singing the song 'Ni hablar, mujer' in a joyous manner. The lyrics of this song are suitably light-hearted and sung with relish by all:

Que retechula es la mujer

Cuando nos quiere de verdad

Pero caray a la hora de pelear

Que le aguante su mamá

¡Ni hablar mujer!

Nací pelado, sí señor,

Pero me gusta, iQue caray!

(How beautiful is a woman

When she really loves us,

But man, when it comes to fighting,

Let her mother put up with her

Don't even mention it!

I was born broke, yes sir,

But I like it, what a fix!)

This song performs several functions within the film. First of all, it establishes the locale, an impoverished but happy barrio in Mexico City, which is seen to be united as all of its members, led by Pepe el Toro, the character played by Infante, in song and

\footnotetext{
${ }^{31}$ Monsiváis, Carlos, and Bonfil, Carlos , A través del espejo: El cine mexicano y su público, (Mexico City: Ediciones el Milagro, 1994), p. 26.
} 
dance. It also tells us a great deal about the plot, which has as one of its dramatic twists the idea of the troublesome women alluded to playfully here in the form of the unfit mother La tísica, Pepe's sister, whose moral and social transgressions have led her to be banished from her community and left him to bring up her daughter as if she were his own. This verse also suggests Pepe's key flaw - his inability to forgive, which has compounded an already difficult situation and will lead to problems in his romantic relationships. Finally, and most importantly, the song touches on the real-life issue of the poverty endured by many migrants to major cities in the Mexico of the 1940s. Pepe is poor but noble, and he not only endures his situation as someone in straightened financial circumstances but actually celebrates it, insisting that being poor makes him happy. Thus he is presented as the ideal Mexican barrio dweller, poor but content with his station in life and a shining embodiment of mexicanidad in his singing prowess and success with the women in the film.

In contrast, the opening song of Gran Casino, 'Dueña de mi amor', does little or nothing to establish the plot of the film:

Tengo un cantar en el pecho

Que dice de tus promesas vanas

Tengo una sed que me abraza los labios

Puede que no se apaga.

Tanto en mi amor y en mi pena

Quiero decirte mi dueña

Que jamás quiero olvidar

No me importa que pueda pasar.

(I have a song inside me

That speaks of your hollow promises

I have a thirst on my lips

That may never be quenched

Both in my love and my pain

I want to declare you my Mistress

Whom I never want to forget

Come what may.) 
Here, the lyrics have no bearing on the narrative as the film opens, for Gerardo has yet to meet Mercedes, and she never betrays him like the woman remembered in this song. Even if it is read as presaging their relationship, their passion is something of a damp squib that has nothing to approach the depth of passion felt by the lover here. This song is thus reduced to a musical interlude that allows Negrete to showcase his singing skills. Lamarque fared little better with her musical numbers. One of these in particular, 'El reflector de mi amor' has her shine torches into the crowd as she sings of her quest to find a decent and solvent man. This frivolous number does not suit her rather regal and haughty bearing and has the effect of being farcical rather than amusing.

Buñuel appears to have disregarded the extent to which Mexican audiences saw the songs that punctuated their favourite films as a key marker of their unique Mexican identity and thus an aspect of filmmaking that was to be taken very seriously. Although he does acknowledge that local audiences prefer their own country's musical through his portrayal of the casino audience violently rejecting Scottish and opera music, he was unable to present Argentine music in anything other than a positive light because Lamarque was one of his stars. As a consequence, life imitated art and the audience of Gran Casino did not appreciate a film whose music was as Argentine as it was Mexican and thus failed to reflect their own idealised notions of what constituted a faithful reflection of Mexican culture. The many departures from the standard musical in Gran Casino led Acevedo-Muñoz to conclude that:

By slightly overemphasizing and parodying the management of the musical numbers, the violence [...] and the romantic conventions [...]Buñuel turns Gran Casino into a parody of itself and of its dying genre. ${ }^{32}$

Buñuel was to pay a high price for his irrevererence - he did not work again for three years and even then he was forced to make another commissioned film, El gran calavera (1949), a generic comedy that displays little if any of his characteristic iconoclasm.

\footnotetext{
${ }^{32}$ Acevedo-Muñoz, 2000, p.50.
} 
Despite the failure of Gran Casino, Buñuel's continuing delight in disrupting the expectations of Mexican audiences is clear from his discussion with Dancigers about their most famous collaboration, Los olvidados (1950). He had evidently not relinquished his desire to experiment with music, as he proposed the inclusion of decidedly disruptive musical elements in a pivotal scene:

Al escribir el guión, yo quería introducir algunas imágines inexplicables, muy rápidas, que habrían hecho decir a los espectadores: ¿he visto bien? Por ejemplo, cuando los chicos siguen al ciego en el descampado pasaban ante un gran edificio en construcción y yo quería instalar una orquestra de cien músicos tocando en los andamios sin que se les oyera. Óscar Dancigers, que temía el fracaso de la película, me lo prohibió.

(While I was writing the script, I wanted to introduce some inexplicable, very fleeting images that would have made the spectators say: Am I seeing things? For example, when the kids follow the blind man onto the waste ground they passed in front of a huge building in the process of being built and I wanted to put an orchestra of 100 musicians playing on the scaffolding in complete silence. Oscar Dancigers, who was worried that the film would be a flop, wouldn't let me do it. $)^{33}$

Ultimately, music plays a minor role in the film and Buñuel came under fire instead for portraying a grim, impoverished and violent urban barrio far removed from the romantic portrayal of urban poverty in Nosotros los pobres. His depiction of a distant, unloving mother was the particular target of local criticism at the time. This element of the film again violates the norms of mexicanidad, where the mother, who is the real-life reflection of the Virgin de Guadalupe, is endlessly giving and selfsacrificing and would rather die than see her children suffer. The harried mother in Los olvidados, who is left to fend for several children on her own and has no patience with her delinquent son Pedro was portrayed in a hard-hitting manner that proved too much for Mexican audiences. Her refusal to feed her son led to a virulent rejection of

\footnotetext{
${ }^{33}$ Buñuel, Luis , Mi último suspiro, (Barcelona: De Bolsillo, 2004), p. 234.
} 
the film even from his crew members, including the set hairdresser who resigned in protest as she insisted that no Mexican mother would behave in this manner. ${ }^{34}$ The reaction to the film was no less extreme when it was released:

After the film's premiere, influential members of the Mexican film business and intellectual circles accused Buñuel of betraying the country that had granted him refuge, and of painting a false picture of Mexico's displaced. The film only screened for four days in the capital's cinemas before being withdrawn. ${ }^{35}$

The director himself remembers the public reaction to the film as follows:

Estrenada bastante lamentablemente en México, la película permaneció cuatro días en cartel y suscitó en el acto violentas reacciones. Uno de los grandes problemas de México, hoy como ayer, es un nacionalismo llevado hasta el extremo que delata un profundo complejo de inferioridad. Sindicatos y asociaciones diversas pidieron inmediatamente mi expulsión. La prensa atacaba a la película. Los raros espectadores salían de la sala como de un entierro.

Screened rather lamentably in México, the film stayed on screens for four days and provoked violent reactions. One of the great problems of México, both now and in the past, is a nationalism that is so extreme that it suggests a profound inferiority complex. Unions and various organisations demanded my immediate expulsión, The press attacked the film. The few viewers left the cinema as if they were leaving a funeral. ${ }^{36}$

The support of Octavio Paz and the film's success at the 1950 Cannes Film Festival, where it won the Palme d'Or, radically changed its reception in Mexico. Overnight, the film was feted and went on to be a smash hit, assuring Buñuel's position as an imminent director. While it is understandable that audiences so accustomed to romantic portrayals of their nation would react strongly against such an unvarnished depiction of troubling social problems, it was easy to accuse a foreign national,

\footnotetext{
${ }^{34}$ Buñuel, 2004, p. 235.

${ }^{35}$ Ibáñez, Juan Carlos, and Palacio, Manuel, 'Los Olvidados/The Young and the Damned,' in The Cinema of Latin America, ed. By Alberto Elena and Marina Díaz López, (London: Wallflower Press, 2003, pp.53-63, p.55.

${ }^{36}$ Buñuel, 2004, pp. 195-6.
} 
especially one from a former colonial power, of being out of touch with the nation he sought to represent. Paradoxically, it was precisely the detachment that Buñuel's position as an outsider in a carefully controlled, hypernationalistic cinematic industry that allowed him to bypass cinematic norms and present a new vision of a violent, dysfunctional Mexico that was to influence generations to come. The deceptively generic Gran Casino and the much more overtly radical Los olvidados thus marked a transition from a sanitized portrayal of a society to a more personal and decidedly more critical independent film practice that is perhaps the true Golden Age of Mexico's cinema. 